\title{
Formulation and Optimization of Piroxicam Orodispersible Tablets by Central Composite Design
}

\author{
E. Bhargav*, C.Surya Prakash Reddy, C.Sowmya, C.Haranath, K.Arshad Ahmed Khan, K.Rajesh, B.Srinath \\ Raghavendra Institute of Pharmaceutical Education and Research, K.R. Palli cross, near S.K University, Anantapur, Andhra Pradesh, INDIA.
}

\begin{abstract}
Objective: The present work was designed to formulate and optimize Orodispersible tablets of Piroxicam using QbD approach. The central composite design tool was used to evaluate the scientific understanding of input and output variables to construct design space for regulatory flexibility. Methodology: The concentrations of super disintegrants were selected as independent variables. The dependent variables selected were in vitro dispersion time and percentage drug release. The quantitative effect of independent variables at different levels on response variables was predicted using polynomial equations. The model was found to be nonlinear and the curvature effect was significant. Therefore study resorted to composite design for optimization. Results and Discussion: DSC studies indicated drug and excipients were compatible. Precompression parameters indicated fairly good flow properties. Tablets were prepared by direct compression method and all the tablets prepared in the above studies were evaluated for pharmacotechnical properties and were found to be within specified limits. Increase in the concentration of Sodium starch glycolate (SSG), Crospovidone (CP) decreased the in vitro dispersion time and increased percentage drug release. Kinetic studies revealed that drug release from all formulations followed first order release. The relationship
\end{abstract}

between independent variables and dependent variables was further elucidated using contour plots. Based on these plots most economical batch was decided which were in desired range. The statistical model is mathematically valid as the experimental values and predicted values suggested by the full model were relatively close to each other. Conclusion: The results demonstrated the effectiveness of the proposed design for development of Piroxicam orodispersible tablets with optimized properties. Key words: Piroxicam, Croscarmellose sodium (CCS), Sodium starch glycolate (SSG), Crospovidone (CP), Central composite design.

Correspondence :

E. Bhargav,

Raghavendra Institute of Pharmaceutical Education and Research, K.R. Palli Cross, Near S.K University, Anantapur -515721, Andhra Pradesh, INDIA.

Phone no. 9052510092

Email: bhargaveranti@yahoo.com

DOI: 10.5530/jyp.2017.9.37

\section{INTRODUCTION}

The oral route is the best way of administering drugs. Different dosage forms administered orally, the tablet is one of the most chosen dosage forms amongst them because of its ease of manufacturing, convenience in administration, precise dosing, and stability when compared with oral liquids because it is more tamper proof than capsules. ${ }^{1}$ Difficulty in swallowing is a common problem of all age groups, especially elderly and child patients, due to physiological changes associated with these groups. These problems can be solved by improvement of a novel type of solid dosage form, namely, orodispersible tablet (Mouth melt tablet), which disintegrates and melts rapidly in saliva without the need of swallowing with drinking water since the tablet is placed in the mouth where it disperses rapidly before swallowing. ${ }^{2,3}$ Orodispersible tablets are also known as mouth dissolving tablets, melt-in-mouth tablets, fast dissolving tablets, rapid melts, porous tablets and quick dissolving tablets. ${ }^{4}$ Piroxicam is the most commonly prescribed NSAIDs for the treatment of pain, inflammation, and stiffness caused by rheumatoid arthritis and osteoarthritis. Superdisintegrants provide quick disintegration due to combined effect of water absorption and swelling by the formulation. Due to swelling of super disintegrants, the wetted surface of the carrier increases, this promotes the wettability and dispersibility of the system, thus improving the disintegration and dissolution.

The experimental designs were selected based on a number of factors, their levels, and possible interactions. ${ }^{5}$ Central Composite design is a better design that combines the advantages of factorial design or fractional factorial design and the star design and is developed by Box and
Wilson. The model is validated using ANOVA. The design space is the multidimensional combination and interaction of input variables (e.g.,material attributes) and process parameters that have been demonstrated to provide the assurance of quality according to ICH Q8 (R2). In the present study, an attempt was made to develop mouth dissolving tablets of Piroxicam by central composite design to investigate the effect of the superdisintegrants on the release profile of the drug.

\section{MATERIALS AND METHODS}

Piroxicam (Tablets India Ltd, Chennai, India), croscarmellose sodium, sodium starch glycolate, and Aspartame (Ranbaxy, New Delhi, India). Crospovidone(Concertina Pharma Pvt., Ltd, Hyderabad, India). Sodium saccharin, mannitol, polyvinylpyrrolidone (PVP), talc, and magnesium stearate were purchased from S.D. Fine Chemicals, Mumbai, India.

\section{METHODS}

\section{Compatibility studies}

\section{Differential Scanning Calorimeter (DSC)}

The drug and excipients were passed through the \#60 sieve and mixed. Accurately transferred $5 \mathrm{mg}$ of drug alone, a mixture of drug and excipients into the pierced DSC aluminum pan and scanned at the temperature range of $25-210^{\circ} \mathrm{C}$ heating rate of $10^{\circ} \mathrm{C} / \mathrm{min}$. The thermograms obtained 
were compared for any interaction between the drug and excipients with that of thermogram of drug alone. ${ }^{6}$

\section{Optimization by the Central composite design}

In the present investigation, $2^{3}$ full factorial design with 4 replicates were selected for the design of experimentation of tablets. The model was found to be nonlinear and the curvature effect was significant. Therefore study resorted to central composite design for optimization. In this design, three factors each were evaluated at three levels. The concentration of superdisintegrants, Sodium starch glycolate (X1), Croscarmellose sodium (X2), Crospovidone (X3) were selected as independent variables and In vitro dispersion time and percentage drug release were selected as dependent variables. The experimental trials were executed at all fifteen possible combinations, as reflected from Table 1.

\section{Pre-compression parameters}

Bulk density (BD)

The bulk density was determined by transferring the accurately weighed blend sample into the $100 \mathrm{ml}$ graduated cylinder by keeping it in a slanting position. The initial volume and weight were noted. The ratio of weight of the sample to the volume it occupied was calculated. ${ }^{7}$

Tapped density (TD)

Tapped density was determined by transferring the accurately weighed blend sample into $100 \mathrm{ml}$ measuring cylinder which was placed in Electrolab Tapped Density Apparatus ( method USP-I ). Initial volume $\left(\mathrm{V}_{0}\right)$ of the cylinder was noted and then the cylinder was tapped for 10 times and the volume was measured. Further additional 500 tapings were made and the volume was noted. Continue the tapings to 1250 if the difference between the volume measured after 10 and 500 tapings was more than $2 \mathrm{ml}^{7}$

\section{Compressibility index (CI)}

Compressibility index (CI) is a measure of the propensity of a powder to be compressed. It is a direct measurement of potential powder arch or the bridge strength and stability. It was calculated according to the equation given below, ${ }^{7}$

$$
\mathrm{CI}=\left(\mathrm{TD}-\frac{\mathrm{BD}}{\mathrm{TD}}\right) \times 100
$$

Hausner ratio: Hausner ratio is an indirect index of ease of powder flow. It was calculated by the following formula: ${ }^{7}$

$$
\text { Hausner ratio }=\text { Tapped density/Bulk density }
$$

Lower Hausner ratio $(<1.25)$ indicates better flow properties than higher ones $(>1.25)$.

\section{Angle of repose}

The angle of repose (a) was determined using funnel method. The blend was poured through a funnel that can be raised vertically to a maximum cone height (h) was obtained. The radius of the heap (r) was measured and angle of repose was calculated.

$$
\mathrm{a}=\tan ^{-1}(\mathrm{~h} / \mathrm{r})
$$

\section{Preparation of Orodispersible tablets of Piroxicam}

A total of fifteen formulations (F1 to F15) of Piroxicam orodispersible tablets were prepared using three superdisintegrants namely Croscarmellose sodium, Crospovidone and Sodium Starch Glycolate by direct compression method. All the ingredients were passed through sieve no. 60 separately and collected. The drug, microcrystalline cellulose, and mannitol were mixed evenly with gentle trituration using mortar and pestle to get a uniform mixture. The required quantity of superdisintegrants and aspartame were taken for each specified formulation and mixed with the above mixture. Finally, magnesium stearate and menthol were added and mixed well. The resulting uniform blends of composition per tablet as mentioned in Table 3 were directly compressed using $7 \mathrm{~mm}$ punch on 12 stations "B" Tooling Rotatory Tablet Compression Machine (Rimek) to produce convex faced tablets. The tablet press setting was kept constant for all formulations. ${ }^{8}$

\section{Physical characterization of the tablets Weight variation}

20 randomly selected tablets were weighed individually; the average weight and the standard deviation were calculated. ${ }^{9}$

\section{Tablet thickness}

Three tablets were taken and their thickness was recorded using Vernier caliper scale. ${ }^{9}$

\section{Hardness}

For each formulation, the hardness of three tablets was determined using the Monsanto hardness tester. The tablet was held along its oblong axis in between the two jaws of the tester. At this point, reading should be zero $\mathrm{kg} / \mathrm{cm}^{2}$. Then constant force was applied by rotating the knob until the tablet fractured. ${ }^{9}$

\section{Friability}

Friability of the tablets was determined using Roche friabilator at $25 \mathrm{rpm} / \mathrm{min}$ for $4 \mathrm{~min} .40$ tablets were weighed and loss in weight (\%) was calculated. ${ }^{9}$

$$
\begin{gathered}
\text { Friability }=(\mathrm{W} 1-\mathrm{W} 2) / \mathrm{W} 1 \times 100 \\
\text { Weight of } 40 \text { Tablets }=\mathrm{W} 1, \\
\text { Weight of } 40 \text { Tablets after friability }=\mathrm{W} 2
\end{gathered}
$$

\section{Drug content}

Five tablets from each formulation were weighed individually and powdered. The Powder equivalent to $20 \mathrm{mg}$ of Piroxicam was weighed and dissolved in $10 \mathrm{ml}$ of methanol and volume was adjusted to $100 \mathrm{ml}$ with pH 6.8 buffer. From this solution $1 \mathrm{ml}$ was taken and made up to $100 \mathrm{ml}$ using a pH6.8 buffer and the solution was analyzed at $333 \mathrm{~nm}$ by UV-visible spectrophotometer using pH 6.8 buffer as the blank. ${ }^{7}$

\section{In vitro Disintegration time}

Disintegration or, more specifically, dispersion times, was measured in $900 \mathrm{ml}$ purified water according to the I.P. method without using a disc at room temperature $\left(25 \pm 2{ }^{\circ} \mathrm{C}\right) .{ }^{10}$

\section{Water absorption ratio}

Water absorption ratio was determined by the method described by Milind et al.

\section{In vitro dispersion time}

The tablet was added to $10 \mathrm{ml}$ of phosphate buffer solution ( $\mathrm{pH}$ 6.8) at $37 \pm 0.5^{\circ} \mathrm{C}$. The time required for complete dispersion of a tablet was measured.?

\section{In vitro drug release}

Dissolution profiles of Piroxicam tablets were determined using the USP 24 method II with a paddle (Electro lab) speed at 50 RPM. Dissolution was performed in $900 \mathrm{ml}$ of phosphate buffer ( $\mathrm{pH}$ 6.8) maintained at $37 \pm 0.5^{\circ} \mathrm{C}$. Five milliliters of the samples were withdrawn at specified time intervals. The volume of dissolution fluid was adjusted to $900 \mathrm{ml}$ by replacing each $5 \mathrm{ml}$ aliquot withdrawn with $5 \mathrm{ml}$ of phosphate buffer ( $\mathrm{pH}$ 6.8) prewarmed at $37 \pm 0.5^{\circ} \mathrm{C}$. Samples withdrawn were filtered through a Whatman filter paper (no.41), suitably diluted with 
phosphate buffer ( $\mathrm{pH}$ 6.8) and analyzed at $333 \mathrm{~nm}$ using a UV-Visible spectrophotometer (Shimadzu). ${ }^{11}$

\section{STATISTICAL ANALYSIS AND OPTIMIZATION}

Data obtained from all dispersible tablet formulations were analyzed using Sigma Tech software (version 3.1) to generate the study design. The best-fit model was selected based on comparisons of several statistical parameters, provided by Sigma Tech software. In addition, analysis of variance (ANOVA) was used to identify significant effects of factors on response regression coefficients. The relationship between the dependent and independent variables was further elucidated using contour plots. Subsequently, a graphical optimization technique using contour plots were used to generate new formulations with the desired responses. In vitro dispersion time and dissolution studies were carried out on the prepared optimized formulation to verify the theoretical prediction. The relative errors (\%) between the predicted and experimental values for each response were calculated. ${ }^{12,13}$

Stability studies: Stability studies at $40^{\circ} \mathrm{C} \pm 2^{\circ} \mathrm{C} / 75 \% \pm 5 \% \mathrm{RH}$ was carried out for 3 months for an optimized formulation which was filled in HDPE containers. The optimized formulation was evaluated for in vitro dispersion time and in vitro drug release for 3 months respectively. ${ }^{14}$

\section{RESULTS AND DISCUSSION}

\section{Compatibility studies}

Differential Scanning Calorimeter (DSC)

DSC thermographs revealed that the melting point of the pure drug is $204.35^{\circ} \mathrm{C}$ and that of the drug in the formulation is $203.41^{\circ} \mathrm{C}$. As there was no shift of melting point in the formulation as compared to the pure drug, it indicated that there is no chemical and physical interaction which is likely to affect the pharmacotechnical properties of the formulation as illustrated in Figure 1.

\section{Precompression parameters}

The prepared dry blend for all formulations indicated good free-flowing property. The value of compressibility index (CI) was in the range of 12.78 to 22.27 and Hausners ratio was in the range of 1.14 to 1.28 , the results were shown in Table 2.

\section{Post compression parameters}

The post-compression parameters like weight variation, thickness, hardness, friability were in compliance with pharmacopoeial (I.P) standards. The percentage drug content of all the tablets was within the acceptable limits. Crospovidone due to its wicking, capillary action and Sodium starch glycolate due to the easy breakdown of particles, rapid absorption of the drug in the dissolution medium showed faster disintegration time. Croscarmellose sodium due to a reduction in solubility and increase in water absorption ratio disintegrated slowly. Among all formulations, F3 showed more water absorption ratio due to its more swelling and water penetration capacity the results were shown in Table 3.

\section{In vitro Dispersion time}

\section{Final equation in terms of coded factors}

Dispersion time $(\mathrm{Y} 1)=128.6667-2.62 \mathrm{X}_{1}+14.75 \mathrm{X}_{2}-30.875 \mathrm{X}_{3}-6.25$ $\mathrm{X}_{1} \mathrm{X}_{2}-2.5 \mathrm{X}_{1} \mathrm{X}_{3}-90 \mathrm{X}_{2} \mathrm{X}_{3}-4.5 \mathrm{X}_{1}^{2}+3.2917 \mathrm{X}_{2}^{2}+22.0417 \mathrm{X}_{3}^{2}$.

\section{Final equation in terms of actual factors}

Dispersion time $(\mathrm{Y} 1)=128.6667-2.62$ SSG+ 14.75 CCS- 30.875 CP6.25 SSG CCS- 2.5 SSG CP - 90 CCS CP - $4.5 \mathrm{SSG}^{2}+3.2917 \mathrm{CCS}^{2}+$ $22.0417 \mathrm{CP}^{2}$.

The polynomial equations were used to draw conclusions after considering the magnitude of the coefficient and the mathematical sign it carries
Increase in release and decrease in dispersion time of crospovidone may be due to its granular and porous structure, smaller size, increased surface area, high interfacial activity, whereas Sodium starch glycolate due to the easy breakdown of particles and rapid absorption of the drug in the dissolution medium.

\section{Establishing Design space:}

Total design space for dispersion time 25-45 min and for drug release 94-100\%. From contour plots it was found that suitable design space for dispersion time was found between the coded values, $-2-1(7.49,5.25)$ and for drug release the coded values $-1-2(5.25,7.49)$ as illustrated in Figure 4 .The experimental values were in agreement with the predicted values confirming the predictability and validity of the model the results were shown in Table 4.

The optimized formulation showed no significant changes in In vitro Dispersion time and In vitro drug release after 3 months. All the parameters were within specifications.

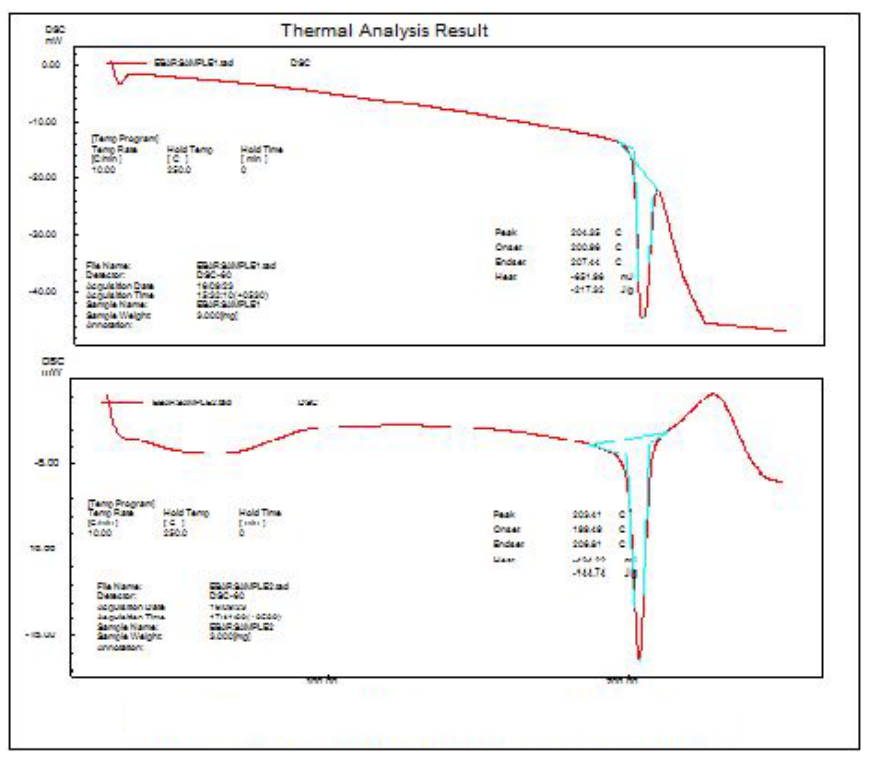

Figure 1: DSC thermogram of Piroxicam pure drug and Stable formulation.

Table 1: Central composite design layout

\begin{tabular}{|c|c|c|c|c|}
\hline \multirow{8}{*}{$\begin{array}{l}\text { Factorial } \\
\text { design }\end{array}$} & Combinations & $\begin{array}{c}\text { SSG (X1) } \\
(\mathrm{mg})\end{array}$ & $\begin{array}{c}\operatorname{CCS}(X 2) \\
(\mathrm{mg})\end{array}$ & $\begin{array}{c}\mathrm{CP}(\mathrm{X} 3) \\
(\mathrm{mg})\end{array}$ \\
\hline & 1 & 3.75 & 4.12 & 4.12 \\
\hline & $\mathrm{X}_{1}$ & 5.25 & 4.12 & 4.12 \\
\hline & $\mathrm{X}_{2}$ & 3.75 & 6.37 & 4.12 \\
\hline & $\mathrm{X}_{1} \mathrm{X}_{2}$ & 5.25 & 6.37 & 4.12 \\
\hline & $\mathrm{X}_{3}$ & 3.75 & 4.12 & 6.37 \\
\hline & $\mathrm{X}_{1} \mathrm{X}_{3}$ & 5.25 & 4.12 & 6.37 \\
\hline & $\mathrm{X}_{2} \mathrm{X}_{3}$ & 3.75 & 6.37 & 6.37 \\
\hline \multirow{4}{*}{ Midpoints } & $\mathrm{X}_{1} \mathrm{X}_{2} \mathrm{X}_{3}$ & 5.25 & 6.37 & 6.37 \\
\hline & Mid-Point & 4.5 & 5.245 & 5.245 \\
\hline & $\mathrm{X}_{1} \mathrm{At}-2 \mathrm{~L}$ & 3.0 & 5.245 & 5.245 \\
\hline & $\mathrm{X}_{1} \mathrm{At}+2 \mathrm{~L}$ & 6.0 & 5.245 & 5.245 \\
\hline \multirow{4}{*}{$\begin{array}{c}\text { Composite } \\
\text { design }\end{array}$} & $\mathrm{X}_{2} \mathrm{At}-2 \mathrm{~L}$ & 4.5 & 2.995 & 5.245 \\
\hline & $\mathrm{X}_{2} \mathrm{At}+2 \mathrm{~L}$ & 4.5 & 7.495 & 5.245 \\
\hline & $\mathrm{X}_{3} \mathrm{At}-2 \mathrm{~L}$ & 4.5 & 5.245 & 2.995 \\
\hline & $\mathrm{X}_{3} \mathrm{At}+2 \mathrm{~L}$ & 4.5 & 5.245 & 7.495 \\
\hline
\end{tabular}


(i.e., positive or negative). ${ }^{15}$ The results of the multiple linear regression analysis revealed that dispersion time decreased with increase in crospovidone and Sodium starch glycolate, dispersion time increased with increase in Croscarmellose sodium. ANOVA was used to identify the significant effect. Obtained value of $\mathrm{F}$ is larger than critical F-value, the result was found to be significant at that level of probability $(p<0.05)$.

\section{In vitro drug release}

In vitro drug release for all formulations found to be $64.5-102.4 \%$ as illustrated in Figure 2, 3.

\section{Final equations in terms of coded factors}

Drug release $(\mathrm{Y} 2)=83.0306+0.375 \mathrm{X}_{1}-0.975 \mathrm{X}_{2}+4.487 \mathrm{X}_{3}+0.825 \mathrm{X}_{1} \mathrm{X}_{2}$ $+1.95 \mathrm{X}_{1} \mathrm{X}_{3}+11.6 \mathrm{X}_{2} \mathrm{X}_{3}+2.6806 \mathrm{X}_{1}^{2}+0.486 \mathrm{X}_{2}^{2}+0.8306 \mathrm{X}_{3}^{2}$.

\section{Final equations in terms of actual factors}

Drug release $(\mathrm{Y} 2)=83.0306+0.375$ SSG- $0.975 \mathrm{CCS}+4.487 \mathrm{CP}+0.825$ SSG CCS + 1.95 SSG CP+ 11.6 CCS CP + 2.6806 SSG ${ }^{2}+0.486 \mathrm{CCS}^{2}+$ $0.8306 \mathrm{CP}^{2}$.

The results of the multiple linear regression analysis revealed that drug release decreased with increase in Croscarmellose sodium, drug release increased with increase in crospovidone and Sodium starch glycolate. ANOVA was used to identify the significant effect. The calculated F value and p-value for a response (Y2) indicate a significant effect of the three factors. ANOVA was used to identify the significant effect. Obtained value of $\mathrm{F}$ is larger than critical F-value, the result was found to be significant at that level of probability $(p<0.05)$. The best fit model with the highest correlation coefficient values or determination coefficients $\left(R^{2}\right)$ for all the formulations followed First order model.

Table 2: Evaluation of Pre-compression parameters

\begin{tabular}{cccccc}
\hline Formulation code & Bulk density $(\mathbf{g} / \mathrm{cm} 3)$ & Tapped density $(\mathbf{g} / \mathrm{cm} 3)$ & Compressibility Index (\%) & Hausner's ratio & Angle of repose \\
\hline F1 & $0.320+0.041$ & $0.408+0.0 .35$ & $21.56+0.341$ & $1.27+0.458$ & $28^{\circ} .32+0.041$ \\
F2 & $0.335+0.020$ & $0.390+0.038$ & $14.10+0.263$ & $1.16+0.257$ & $27^{\circ} .51+0.020$ \\
F3 & $0.374+0.033$ & $0.433+0.019$ & $13.62+0.785$ & $1.15+0.015$ & $31^{\circ} .11+0.033$ \\
F4 & $0.314+0.021$ & $0.404+0.026$ & $22.27+0.887$ & $1.28+0.036$ & $35^{\circ} .63+0.021$ \\
F5 & $0.342+0.043$ & $0.429+0.060$ & $20.27+0.772$ & $1.25+0.896$ & $34^{\circ} .03+0.043$ \\
F6 & $0.334+0.026$ & $0.406+0.023$ & $17.73+0.221$ & $1.21+0.788$ & $30^{\circ} .95+0.026$ \\
F7 & $0.348+0.048$ & $0.399+0.039$ & $12.78+0.669$ & $1.14+0.168$ & $25^{\circ} .42+0.048$ \\
F8 & $0.370+0.032$ & $0.434+0.034$ & $14.74+0.054$ & $1.17+0.018$ & $31^{\circ} .22+0.032$ \\
F9 & $0.317+0.022$ & $0.401+0.014$ & $20.94+0.254$ & $1.26+0.016$ & $31^{\circ} .39+0.035$ \\
F10 & $0.333+0.036$ & $0.407+0.059$ & $18.18+0.147$ & $1.22+0.367$ & $31^{\circ} .23+0.039$ \\
F11 & $0.342+0.024$ & $0.433+0.075$ & $21.01+0.011$ & $1.26+0.782$ & $28^{\circ} .25+0.047$ \\
F12 & $0.344+0.044$ & $0.403+0.013$ & $14.64+0.021$ & $1.17+0.019$ & $29^{\circ} .21+0.026$ \\
F13 & $0.356+0.029$ & $0.427+0.028$ & $16.62+0.126$ & $1.19+0.089$ & $33^{\circ} .01+0.031$ \\
F14 & $0.311+0.049$ & $0.394+0.025$ & $21.06+0.148$ & $1.26+0.147$ & $31^{\circ} .27+0.049$ \\
F15 & $0.358+0.037$ & $0.422+0.029$ & $15.16+0.015$ & $1.17+0.354$ & $32^{\circ} .06+0.036$ \\
\hline
\end{tabular}

All values are expressed as mean + standard deviation $(n=3)$

Table 3: Evaluation of Piroxicam Orodispersible tablets

\begin{tabular}{|c|c|c|c|c|c|c|c|}
\hline $\begin{array}{l}\text { Batch } \\
\text { code }\end{array}$ & $\begin{array}{c}\text { Weight } \\
\text { Variation }(\mathrm{mg})^{*}\end{array}$ & $\begin{array}{l}\text { Thickness } \\
(\mathrm{mm})^{* *}\end{array}$ & $\begin{array}{l}\text { Hardness } \\
\left(\mathrm{kg} / \mathrm{cm}^{2}\right)^{* *}\end{array}$ & $\begin{array}{l}\text { Friability } \\
(\%)^{* * * *}\end{array}$ & $\begin{array}{l}\text { Drug content } \\
(\%)^{* *}\end{array}$ & $\begin{array}{l}\text { Disintegration time } \\
\qquad(\mathrm{sec})^{* *}\end{array}$ & $\begin{array}{l}\text { Water absorption } \\
\text { ratio }(\%)^{* *}\end{array}$ \\
\hline $\mathrm{F} 1$ & $150+2.6$ & $4.18+0.09$ & $2.3+0.110$ & $0.54+0.054$ & $99.37+0.24$ & $23+0.31$ & $92.48+0.19$ \\
\hline $\mathrm{F} 2$ & $152+1.6$ & $4.20+0.023$ & $2.5+0.108$ & $0.23+0.112$ & $99.03+0.77$ & $32+0.65$ & $85.25+1.05$ \\
\hline F3 & $148+1.8$ & $4.19+0.518$ & $2.5+0.648$ & $0.44+0.198$ & $97.31+0.31$ & $158+0.28$ & $94.23+3.82$ \\
\hline $\mathrm{F} 4$ & $149+1.3$ & $4.10+0.603$ & $2.6+0.751$ & $0.21+1.163$ & $97.45+0.22$ & $151+0.37$ & $81.12+2.63$ \\
\hline F5 & $152+1.1$ & $4.16+0.263$ & $2.4+0.253$ & $0.46+0.682$ & $98.90+0.63$ & $55+0.60$ & $82.22+0.65$ \\
\hline F6 & $150+0.8$ & $4.21+0.648$ & $2.7+0.612$ & $0.33+0.263$ & $99.30+0.34$ & $37+0.63$ & $86.1+0.516$ \\
\hline F7 & $149+0.7$ & $4.16+0.733$ & $2.5+0.115$ & $0.24+0.376$ & $98.36+0.67$ & $28+0.68$ & $88.36+1.06$ \\
\hline F8 & $151+2.7$ & $4.13+0.756$ & $2.5+0.130$ & $0.41+0.358$ & $98.66+0.23$ & $20+0.15$ & $93.41+3.12$ \\
\hline F9 & $148+1.2$ & $4.10+0.758$ & $2.3+0.786$ & $0.43+0.421$ & $97.40+0.71$ & $122+1.32$ & $70.1+0.933$ \\
\hline F10 & $150+1.4$ & $4.19+0.985$ & $2.5+0.263$ & $0.24+0.594$ & $98.90+0.63$ & $61+0.66$ & $86.12+0.33$ \\
\hline F11 & $152+0.9$ & $4.22+0.753$ & $2.5+0.682$ & $0.34+0.113$ & $98.42+0.68$ & $65+0.22$ & $88.0+0.122$ \\
\hline F12 & $148+1.8$ & $4.11+0.467$ & $2.2+0.151$ & $0.48+0.367$ & $97.61+0.24$ & $120+0.77$ & $73.1+0.998$ \\
\hline F13 & $150+1.2$ & $4.18+0.033$ & $2.5+0.170$ & $0.21+0.385$ & $98.63+0.76$ & $63+0.91$ & $86.3+0.132$ \\
\hline F14 & $152+1.3$ & $4.12+0.067$ & $2.5+0.131$ & $0.14+0.412$ & $98.99+0.63$ & $87+0.77$ & $79.1+0.662$ \\
\hline F15 & $151+1.1$ & $4.23+0.054$ & $2.3+0.251$ & $0.36+0.594$ & $99.04+0.67$ & $82+0.88$ & $80.2+0.343$ \\
\hline
\end{tabular}

All values are expressed as mean + standard deviation $\left(n=20^{*}, n=3^{* *}, n=40^{* * *}\right)$ 


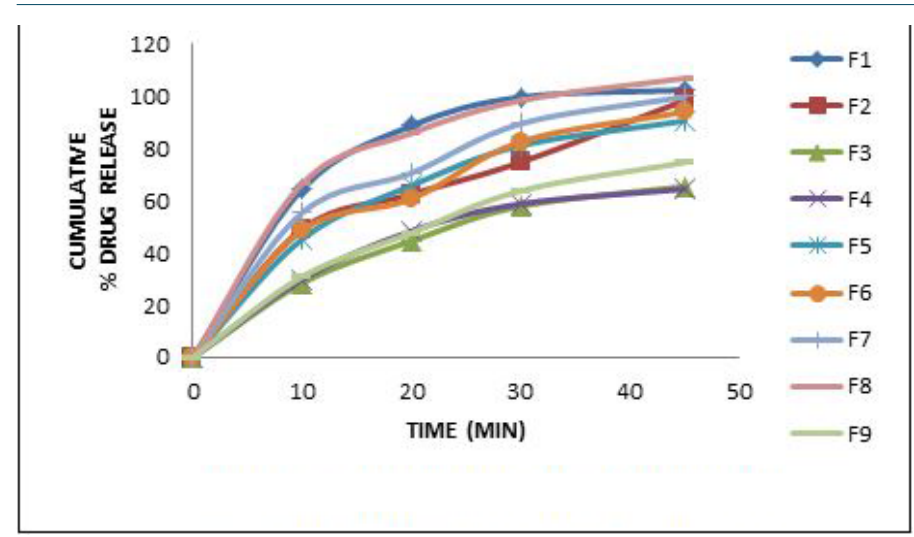

Figure 2: In vitro drug release of Piroxicam from formulations (F1-F9).

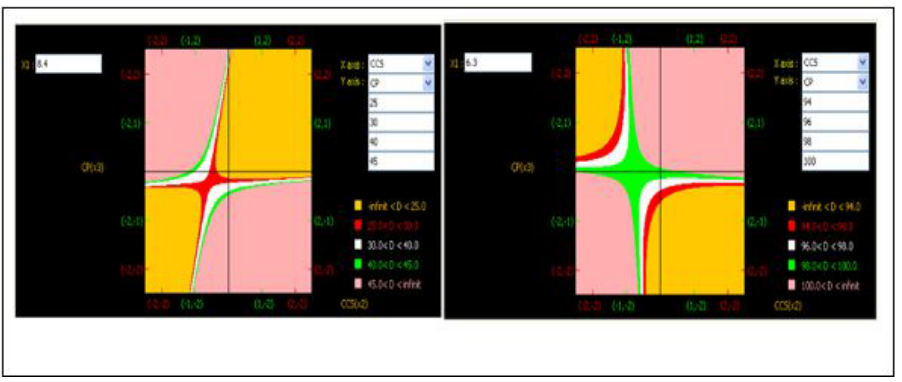

Figure 4: Contour plots for Piroxicam Orodispersible tablets

\section{CONCLUSION}

In this study, the concentration of various superdisintegrants was observed to have a profound and interactive effect on the dispersion time and drug release as shown by the model obtained using central composite design. The data observed showed this experimental design was successfully applied to optimize the concentration of various superdisintegrants to formulate Orodispersible tablets with desirable properties of low dispersion time and high drug release. It can be concluded that central composite design could be successfully applied for the development of Piroxicam Orodispersible tablets with fewer numbers of trials and better quality attributes.

\section{ACKNOWLEDGEMENT}

The authors are thankful to RIPER for providing necessary facilities to carry out the work.

\section{CONFLICT OF INTEREST}

No conflict of interest are declared.

\section{ABBREVIATIONS USED}

QbD: Quality by design; ANOVA: Analysis of variance.

\section{REFERENCES}

1. Chein Yie W. Oral drug delivery and delivery systems. 2nded. Marcel Dekker. New York: 1992

2. Bi Y, Sunada H, Danjo K, Otsuka A. Preparation and evaluation of a compressed tablet rapidly disintegrating in the oral cavity. Chem Pharm Bull. 1996;44(11):2121-7. https://doi.org/10.1248/cpb.44.2121 PMid:8945778.

3. Bi Y, Sunada H, Danjo K, Yonezawa Y. Evaluation of rapidly disintegrating tablets

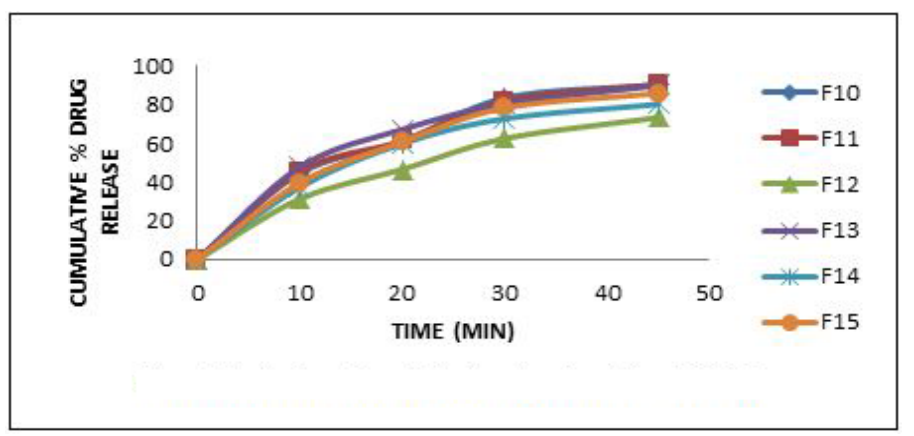

Figure 3: In vitro drug release of Piroxicam from formulations (F10-F15).

Table 4: Comparison of experimental results with predicted responses of Piroxicam orodispersible tablets formulation

\begin{tabular}{cccccc}
\hline Ingredient & $\begin{array}{c}\text { Composition } \\
(\mathrm{mg} / \mathrm{tab})\end{array}$ & Response & $\begin{array}{c}\text { Predicted } \\
\text { value }\end{array}$ & $\begin{array}{c}\text { Experimental } \\
\text { value }\end{array}$ & $\begin{array}{c}\text { Standard } \\
\text { error }\end{array}$ \\
\hline SSG & 5.25 & Y1 (DT) & 41.04 & 38.05 & $1.49 \%$ \\
& & $(\mathrm{sec})$ & & & \\
CCS & 5.25 & Y2(DR) & 102.1 & 99.8 & $1.10 \%$ \\
& & $(\%)$ & & \\
CP & 7.49 & & & \\
\hline
\end{tabular}

prepared by a direct compression method. Drug Dev Ind Pharm. 1999;25(5):571-81 https://doi.org/10.1081/DDC-100102211 PMid:10219525.

4. Sreenivas SA, Dandagi PM. Orodispersible tablets: Newfangled drug delivery system-A review. Indian J Pharm Educ Res. 2005;39(4):177-81.

5. Cavazzuti M. Optimization Methods: From Theory to Design scientific and technological aspects. 1st ed: Springer-Verlag Berlin Heidelberg. 2013;262. https:// doi.org/10.1007/978-3-642-31187-1.

6. Bhargav E, Harish P, Haranath C, Suryaprakash C. Formulation and Optimization of gastro retentive extended-release floating tablets of Tramadol Hydrochloride. Inventi spreading knowledge. 2016;4:1-8.

7. Milind Wagh P, Chetan Yewale P, Santosh Zate U, Paresh Kothawade I, Ganesh Mahale H. Formulation and evaluation of Fast Dispersible tablets of Aceclofenac using different Superdisintegrants. Int J Pharm Pharm Scilnt J Pharm Pharm Sci. 2010;2:154-7.

8. Ravi Kiran N, Palanichamy S, Rajesh M, Godwin T, Rajadhas, Anusha V, Parasakthi N, Thanga Thirupathi A. Formulation and evaluation of orodispersible tablets Piroxicam tablets. J Pharm Sci Res. 2010;2(10):615-21.

9. Pabari RM, Ramtoola Z. Effect of disintegration mechanism on wetting, wate absorption and disintegration time of Orodispersible tablets. J young Pharm 2012;4:157-63. https://doi.org/10.4103/0975-1483.100021 PMid:23112534 PMCid:PMC3483525.

10. Indian Pharmacopoeia, Government of India, ministry of health and family welfare. 4th ed. New Delhi: Controller of Publication of India; 1996.

11. Venkata Naveen Kasagana SSK, Thirumal M. Formulation and Evaluation of fast dissolving Piroxicam tablets using different Superdisintegrants. Int J Pharm Pharm Sci. 2012;4(2):334-7.

12. Chappidi Suryaprakash Reddy, Y Padmanabha Reddy, Nayakanti Devanna Formulation and Optimization of the extended release tablets of Dalfampridine by 23 factorial design. Journal of Pharmaceutical and Scientific Innovation. 2016;5(1):27-37. https://doi.org/10.7897/2277-4572.0517.

13. YB Bansod YD, AE Shirsat. Quality by Design approach to the development of Verapamil Hydrochloride floating matrix tablet. Am J Pharm Tech res. 2014;4:890-904

14. Amaresh Prusty, Amiya kanta Mishra, Bijon Kumar Gupta. Development and evaluation of matrix tablet by taking new chemicals combination of chitosan and eudragit-I 100. J young Pharm. 2016;8(3):168-76. https://doi.org/10.5530/ jyp.2016.3.2.

15. Gohel M PM, Amin AM, Agrawal R, Dave R, Bariya N. Formulation design and optimization of mouth dissolve tablets of nimesulide using vacuum drying technique. AAPS Pharm Sci Tech. 2004;5:36. https://doi.org/10.1208/pt050336 PMid:15760070 PMCid:PMC2750260. 